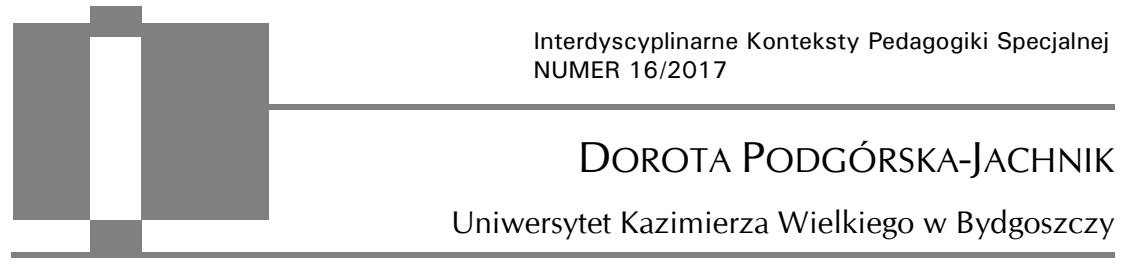

\title{
Wsparcie społeczne dla osób z niepełnosprawnością a refleksja nad "dobrą" i "złą" charytatywnością
}

\begin{abstract}
Dorota Podgórska-Jachnik, Wsparcie społeczne dla osób z niepetnosprawnościa a refleksja nad "dobra" $i$ "zła" charytatywnościa [Social support for people with disability and reflection on "positive" and "negative" charities]. Interdyscyplinarne Konteksty Pedagogiki Specjalnej, nr 16, Poznań 2017. Pp. 185-206. Adam Mickiewicz University Press. ISSN 2300-391X

Difference/disability is associated with limitations in social contacts and the risk of social exclusion. Charity and philanthropy not only are an opportunity for people with disabilities but also pose a threat. The article deals with "positive" and "negative" charities, as well as ethical guidance to these activities. The text asks about the 21st century model of NGOs support for people at risk of social exclusion.
\end{abstract}

KEY WORDS: charity, philanthropy, disability, social support, ethical guidelines

Inny w dyskursie polskiej pedagogiki specjalnej ostatnich lat to umowny, zbiorowy deskryptor wszystkich kategorii osób zagrożonych wykluczeniem społecznym z powodu swojej odmienności ${ }^{1}$. Pedagogika specjalna podkłada pod to pojęcie w pierwszym rzędzie niepełnosprawność, ale także każdą kategorię osób wymagających

1 Zob. Obszary społecznej marginalizacji - niepetnosprawność, red. J. Rutkowiak, A. Krause, OSW im. J. Rusieckiego, Olsztyn 2009. 
mniejszego lub większego wsparcia społecznego. Analizując z kolei źródła wsparcia społecznego, można wskazać ich wiele, a jednym z celów współczesnych działań pomocowych (w tym polityki społecznej, pomocy społecznej czy pracy socjalnej) jest poszukiwanie i aktywizacja jego zasobów ${ }^{2}$. Takimi mogą być zarówno różnego rodzaju działania charytatywne, jak i w ogóle zasoby budowane w ramach tzw. trzeciego sektora, czyli różnego rodzaju organizacji pozarządowych, popularnie określanych w Polsce jako NGO lub NGOs (w liczbie mnogiej) od skrótu ich angielskiej nazwy nongovernmental organization (organizations). Warto zaznaczyć, że skróty te używane są w oficjalnych dokumentach zarówno krajowych, jak zagranicznych. W przypadku w pełnej zależności od państwa a może to być zarówno zależność ekonomiczna, jak i polityczna czy ideologiczna - używa się też skrótu QUANGO (Quasi-NGO)³, choć nie jest on już tak rozpoznawalny jak poprzednie.

W Polsce organizacje wspierające osoby z niepełnosprawnością obecne są od dawna, już od XIX w., najstarsza z nich na terenie ziem polskich to powstałe we Lwowie już w 1876 r. Galicyjskie Towarzystwo Głuchoniemych „Nadzieja” (później przemianowane na Małopolskie Towarzystwo Głuchoniemych „Nadzieja”)4. Od tego czasu utworzono szereg innych, działających do dziś stowarzyszeń, a wśród nich takie rozwinięte na skalę ogólnopolską wielkie instytucje społeczne, takie jak Polski Związek Głuchych, Polskie Stowarzyszenie na rzecz Osób z Upośledzeniem (od roku 2015 Polskie Stowarzyszenie na rzecz Osób z Niepełnosprawnością intelektualną), Polski Związek Niewidomych, Polskie Towarzystwo Walki z Kalectwem i wiele innych. Mają one swoją kilkudziesięcioletnią

2 D. Podgórska-Jachnik, Praca socjalna z osobami z niepetnosprawnością $i$ ich rodzinami, CRZL, Warszawa 2014.

${ }^{3}$ Elementarz III sektora, Stowarzyszenie Klon/Jawor, Warszawa 2005, http:/ /www. ngo.pl/files/biblioteka.ngo.pl/public/ksiazki/Klon/elementarz_III_sektora.pdf [dostęp: 17.05.2017].

${ }^{4}$ B. Szczepankowski, Historia ruchu głuchoniemych. Publikacja wydana z okazji 120-lecia ruchu społecznego niesłyszących na ziemiach polskich oraz 50-lecia Polskiego Związku Głuchych, PZG, Warszawa 1997. 
tradycję, jednak ich intensywny rozwój - podobnie zresztą jak organizacji pozarządowych działających na rzecz innych grup społecznych i powołanych w najróżniejszych innych celach - przyniosła transformacja ustrojowa lat 90 ., a nową przestrzeń do działania stworzyła Ustawa z dnia 24 kwietnia 2003 r. o działalności pożytku publicznego i o wolontariacie ${ }^{5}$, znowelizowana w kolejnych latach ${ }^{6}$, z uwzględnieniem doświadczeń pierwszych lat wolontariatu jako zjawiska, które wcześniej nie było w Polsce przewidywane prawnie. To istotna uwaga, gdyż wskazuje, jak bardzo jako naród musieliśmy się uczyć nowej rzeczywistości, łącznie $\mathrm{z}$ nadawaniem nowego kształtu działaniom społecznikowskim.

W celu zaznaczenia społecznej funkcji organizacji pozarządowych używa się też wobec nich określenia "organizacje użyteczności publicznej” lub „pożytku publicznego", choć z punktu widzenia ich szczególnego statusu (np. prawa pozyskiwania środków finansowych ze zbiórek publicznych, $\mathrm{w}$ tym $\mathrm{z}$ deklaracji podatników co do przeznaczenia $1 \%$ podatku dochodowego), nie wszystkie NGOs można uznać za takowe w świetle istniejącego prawa. Pożytek publiczny w nazwie kategorii organizacji nie oznacza braku motywów ekonomicznych czy nawet możliwości zarobkowania przez nią, ale wskazuje na motyw pro publico bono jako wiodący i podporządkowujący wszystkie pozostałe. Co więcej, podlega to podstawowej kontroli systemowej poprzez obowiązek corocznego składania i upubliczniania sprawozdań finansowych. Nie znaczy to, że organizacje te nie mogą się kierować czy nie kierują się w swoim działaniu motywami ekonomicznymi, chęcią pozyskania środków finansowych do realizacji swoich celów, w tym chęcią polepszenia sytuacji życiowej swoich członków czy reprezentowanej społeczno-

${ }^{5}$ Ustawa z dnia 24 kwietnia 2003 r. o działalności pożytku publicznego i o wolontariacie (Dz. U. Nr 96 z 2003 r., poz. 873).

${ }^{6}$ Ustawa z dnia 24 kwietnia 2003 r. o działalności pożytku publicznego i o wolontariacie. z późn. zmianami - tekst ujednolicony na podstawie Obwieszczenia Marszałka Sejmu Rzeczypospolitej Polskiej z dnia 1 lutego 2016 r. w sprawie ogłoszenia jednolitego tekstu ustawy o działalności pożytku publicznego i o wolontariacie (Dz. U. z 2010 r. Nr 28, poz. 146). 
ści, jednak społeczna użyteczność jest motywem wiodącym, a inne działania muszą być jej podporządkowane7.

Nazwa trzeci sektor dotyczy podziału podmiotów aktywności społeczno-gospodarczej w nowoczesnych państwach demokratycznych, która obejmuje następujące grupy podmiotów:

- sektor pierwszy - państwowy, którą stanowi administracja publiczna nastawiona na realizację zadań publicznych,

- sektor drugi - prywatny, którą stanowi sfera biznesu, przedsiębiorstw i wszystkich instytucji nastawionych na zysk ekonomiczny,

- sektor trzeci - sektor organizacji pozarządowych, prywatnych, działających społecznie i nie dla zysku (non-profit) $)^{8}$.

W zestawieniu tym określenie pozarządowe odróżnia sektor trzeci od pierwszego, a określenie non-profit - trzeci od drugiego, co przedstawia tabela 1 .

Tabela 1. Podstawowa charakterystyka "trzeciego sektora" w podziale podmiotów aktywności społeczno-gospodarczej państwa (źródło: opracowanie własne na podstawie G. Spytek-Bandurska, Sektor, podmioty, poziomy i organizacja polityki spotecznej, [w:] Polityka społeczna, red. G. Firlit-Fesnak, M. Szylko-Skoczny, Wydawnictwo Naukowe PWN, Warszawa 2009 oraz portalu polskich organizacji pozarządowych www.osektorze.ngo.pl)

\begin{tabular}{|c|c|c|}
\hline Podmioty & Sektor gospodarczy & $\begin{array}{l}\text { Ukierunkowanie } \\
\text { ekonomiczne }\end{array}$ \\
\hline $\begin{array}{l}\text { państwowe, rządowe, } \\
\text { publiczne }\end{array}$ & $\begin{array}{c}\text { PIERWSZY SEKTOR } \\
\text { Instytucje rządowe }\end{array}$ & \multirow{2}{*}{$\begin{array}{l}\text { non-profit, realizacja za- } \\
\text { dań publicznych }\end{array}$} \\
\hline \multirow{2}{*}{$\begin{array}{l}\text { prywatne, pozarządowe, } \\
\text { niepubliczne }\end{array}$} & $\begin{array}{c}\diamond \text { TRZECI SEKTOR } \Rightarrow \\
\text { Organizacje pozarządowe }\end{array}$ & \\
\hline & $\begin{array}{c}\text { DRUGI SEKTOR } \\
\text { Prywatne przedsiębior- } \\
\text { stwa }\end{array}$ & nastawienie na zysk \\
\hline
\end{tabular}

7 Ibidem.

8 Portal organizacji pozarządowych, http:/ / osektorze.ngo.pl [dostęp: 22.04.2017]. 
Organizacje nastawione na działania prospołeczne nazywano niegdyś charytatywnymi i terminy charytatywność, dobroczynność czy filantropia nadal funkcjonują $\mathrm{w}$ dyskursie publicznym, natomiast przemyślenia wymagają zarówno same określenia, jak i podejmowane w ramach nich działania - stąd tytułowe pytanie o "dobrą" $\mathrm{i}$ „złą" charytatywność.

Słowo charytatywny pochodzi z łac. charitas, caritas - miłosierdzie; charitatious - miłosierny, zaś słowo miłosierny wywiedzione jest od słowa miłość - w filozofii i etyce chrześcijańskiej podstawowej relacji istnieniowej, która łącząc ze sobą osoby staje się relacją osobową. Pojęcie miłości jest więc konstytutywne dla założeń chrześcijańskiego personalizmu, a Mieczysław Gogacz określa ją jako podstawę filozofii działań chroniących, gdyż „w miłość osobową włączony jest cały człowiek, gdy intelekt i wola chronią tę relację swoimi działaniami" ${ }^{9}$. Jest to więc miłość cała, zupełna i pełna. Można powiedzieć za autorem o „miłości, chronionej przez poznanie i decyzje". To ważne dookreślenie, gdyż we współczesnym społeczeństwie za działaniami potocznie określanymi jako charytatywne nie zawsze stoją relacje osobowe, nie zawsze towarzyszy im wola i wysiłek poznania Innego, co wobec przytoczonych słów może wręcz zaprzeczać idei miłości określanej personalistycznie.

Istnieje kilka odmian chrześcijańskiej miłości - caritas jest jedną z nich, a ściślej jest jedną z form tzw. miłość umysłowej (łac. dilectio). W ujęciu personalistycznym to nawet nie jakaś działalność społeczna, ale pewna nadrzędna wartość - altruistyczna troska o człowieka, bez oczekiwania wzajemności; uczucie, które stanowi cel sam w sobie. Tylko taką miłość pozwala na ogarnięcie drugiego człowieka w pełni jego bytu. Jak podkreśla Gogacz: „w caritas tak naprawdę najważniejszy jest drugi człowiek oraz jego dobro, jego miłość, tęsknoty, troski, utrapienia"10. Działanie społeczne, akty charytatywności mogą - i oczywiście powinny - wypływać z tak

${ }^{9}$ M. Gogacz, Wprowadzenie do etyki chronienia osób, Wydawnictwo Navo, UKSW, Warszawa 1998, s. 63.

10 Ibidem. 
rozumianej caritas, pozostaje jednak pytanie, czy faktycznie można ją dostrzec jako ideę przewodnią współczesnej pozornie bardzo rozwiniętej charytatywności? Jedną ze sprzeczności jest np. ograniczenie charytatywności do datków finansowych, które mają utrzymać darczyńcę w dobrym samopoczuciu i przekonaniu o jego dobroduszności, bez wejścia w przestrzeń osobistych relacji, o których była mowa wcześniej czy chociaż zainteresowania się losem i faktycznymi potrzebami beneficjentów. Jasne, że w dużej skali i potrzeb, i działań charytatywnych trudno o umożliwienie typowych kontaktów w relacji face-to-face, ale trzeba liczyć się z tym, że charytatywność zbudowana na komunikowaniu masowym, wykorzystująca odruchy emocjonalne i mechanizm zachowań konsumenckich jako bazę fundraisingu (sprofesjonalizowanej formy pozyskiwania środków finansowych na działalność organizacji pozarządowych), wiąże się z ryzykiem uprzedmiotowienia beneficjentów, a nawet budowania i utrwalania niebezpiecznych stereotypów społecznych. Może np. budować wizerunek osoby z niepełnosprawnością, biednej, biernej, nieszczęśliwej, zależnej. To stereotyp przeciwny obrazowi osoby z niepełnosprawnością, jaki mieści się $\mathrm{w}$ teleologii pedagogiki specjalnej, w takim rozumieniu działalność charytatywna mogłaby nawet prowadzić do efektów sprzecznych z celami rewalidacyjnymi.

Jest to zapewne obszar pewnego ryzyka, który wymaga refleksji pedagoga specjalnego, choć nie jest argumentem przeciwko charytatywności jako takiej. Analizując jednak realny obraz podejmowanych w tym obszarze działań (o czym więcej w dalszej części artykułu), jak również ich skutków, można powiedzieć, że przymiotnik charytatywny oderwał się współcześnie od swego źródłosłowu. Stąd też jeśli rozważa się i poddaje krytyce funkcjonowanie ruchu charytatywnego, jak i podejścia charytatywnego do działań pomocowych, nie oznacza to krytyki samej caritas. Co więcej, wydaje się, że formuła caritas jest ponadczasowa, nie może się wyczerpać, natomiast formuła działań charytatywnych zawsze musi być analizowana wobec jakichś realiów rzeczywistości społecznej - jakiegoś tu i teraz. Nie ulega jednak wątpliwości, że do caritas trzeba dojrzewać, 
trzeba się jej uczyć. Tak samo uczyć się trzeba człowieka otaczanego pomocą, gdyż każda forma pomocy jest też ingerencją w świat Innego i jako taka zobowiązuje do szczególnej uważności, odpowiedzialności i etyczności.

Dwa pozostałe wskazane pojęcia dobroczynność i filantropia należałoby traktować jako synonimy. Dobroczynność - według Słownika Języka Polskiego PWN to działalność o charakterze społecznym polegająca na niesieniu pomocy materialnej ubogim ${ }^{11}$, przy bardzo podobnie brzmiącej definicji słowa filantropia (gr. philanthrōpia dobroczynność, życzliwość; philánthrōpos - kochający ludzkość): to działalność osób bądź instytucji polegająca na bezinteresownym udzielaniu pomocy finansowej lub materialnej potrzebującym ${ }^{12}$. Można więc uznać, że słowa dobroczynność, filantropia, beneficencja oznaczają to samo (ostatnie praktycznie w Polsce jest nieużywane, choć za sprawą realizacji różnego rodzaju licznych projektów, finansowanych m.in. ze środków unijnych, samo słowo beneficjent stało się z kolei bardzo popularne).

Paradoks dobroczynności polega na tym, że niewłaściwie realizowana może przynosić wręcz negatywne skutki społeczne, a więc mimo pozytywnych intencji może zamieniać się w złą dobroczynność lub też złoczynność. Czasem trudno zrozumieć, jak to możliwe, że negatywne efekty działań społecznych sytuują się tak daleko od ich pozytywnych założeń. Dla przykładu: z tego samego powodu trudno zrozumieć, dlaczego w coraz większej liczbie krajów kolejne wielkie miasta wprowadzają np. restrykcyjne zakazy dokarmiania bezdomnych, piętnowane jest jako społecznie szkodliwe zasilanie pieniędzmi żebrzących itd. Nie oznacza to przecież zaszczepienia społecznej znieczulicy i wygaszenia gotowości działań pomocowych, a jedynie chęć wzbudzenia refleksji nad perspektywicznym znaczeniem własnych działań - w omawianym przypadku utrwa-

${ }^{11}$ Hasło: dobroczynność, [w:] Słownik języka polskiego PWN, https://sjp.pwn.pl/ doroszewski/dobroczynnosc;5421107.html [dostęp: 2.05.2017].

12 Hasło: filantropia, [w:] Słownik języka polskiego, https://sjp.pl/filantropia [dostęp: 2.05.2017]. 
lania bezdomności. Zakaz dokarmiania bezdomnych obowiązuje już w ponad pięćdziesięciu amerykańskich miastach, $\mathrm{w}$ tym $\mathrm{w}$ takich metropoliach, jak Nowy ork, Los Angeles, Las Vegas, Phoenix Dallas czy Miami, działania takie - uznawane obecnie za przestępstwa - zagrożone są bezwzględnie egzekwowanymi karami grzywny i więzienia, nawet $\mathrm{w}$ odniesieniu do przedstawicieli organizacji charytatywnych, gdyż zarezerwowano je jako usługę socjalną dla wyspecjalizowanych instytucji państwowych ${ }^{13}$. Tak realizowana polityka żywnościowa wobec osób bezdomnych ułatwia bowiem nie tylko ich zliczane (problem występujący we wszystkich krajach), ale także podejmowanie powiązanych z nią działań na rzecz wychodzenia z bezdomności. To drastyczny przykład, ale najlepiej pokazuje dwa skrajne oblicza działań dobroczynnych.

Okazuje się zatem, że nie tylko nie można odrywać działań charytatywnych od uczenia się i dojrzewania $\mathrm{w}$ caritas, ale i filantropii nie można odrywać od realiów i mechanizmów rządzących światem społecznym. Filantropia powinna być bowiem przemyślaną, racjonalną dobroczynnością, wpisaną w jakąś określoną strategię zmieniania świata - jak uważają niektórzy jego "naprawiania”. O ile działania charytatywne mogą być podejmowane przez każdego, o tyle filantropia wymaga dużego nakładu środków na realizację założonych przedsięwzięć: im większy zakres planowanych zmian, tym większych nakładów. Może być zatem udziałem najbogatszych $^{14}$, co budzi czasem skrajne emocje i oceny (stereotyp kapitalisty "krwiopijcy”, który wzbogaciwszy się kosztem innych - bawi się w filantropa), jednak należy z uwagą spojrzeć zasoby - nie tylko finansowe - będące $\mathrm{w}$ posiadaniu najbardziej przedsiębiorczych

${ }^{13}$ Ch. Spargo, Florida charity worker, 90, arrested by police for feeding the homeless gets right gets arrested again one day later, http:/ / www.dailymail.co.uk/news/article2822829/Charity-worker-90-arrested-police-feeding-homeless-gets-right-work-one-daylater-despite-outcry-insensitive-mayor-gets-arrested-again.html [dostęp: 25.11.2016].

14 W Polsce liczba osób z majątkiem wartym ponad $1 \mathrm{mln}$ dolarów wynosiła wg Raportu brytyjskiej firmy MDRC w roku 2008 ponad 78 tys. Zob. Filantropia - Polacy nie znaja tego stowa, wydanie z 27.10.2010, http://wiadomosci.dziennik.pl/wydarze nia/artykuly/307049,filantropia-polacy-nie-znaja-tego-slowa.html [dostęp: 2.05.2017]. 
jednostek. Wbrew krzywdzącym opiniom często są one motywowane rzeczywistą chęcią niesienia dobra i solidarnością z grupami czy jednostkami słabszymi.

Dobra, nowoczesna, wartościowa społecznie i etyczna filantropia nie jest jednak łatwa. Trzeba się jej uczyć. Ciekawe są doniesienia prasowe dotyczące spojrzenia Polaków na filantropię. $\mathrm{Z}$ badania przeprowadzonego na zlecenie Fundacji dla Polski wynika, że

prawie $60 \%$ Polaków twierdzi, że rozumie słowo filantropia. Jednak tylko $18 \%$ potrafi wskazać jego prawdziwą definicję. Ponad połowa $\mathrm{z}$ nas myli filantropię z charytatywnością i proc. podatku przekazywanego na organizacje pożytku publicznego. W odróżnieniu od kogoś, kto udziela się charytatywnie (współczuje innym i ma nagłą potrzebę udzielenia im pomocy), filantrop to osoba, która starannie planuje sposób, w jaki pomaga (wie o tym zaledwie $18 \%$ badanych) i potrafi czekać na rezultaty swojej działalności (3,7\% badanych) ${ }^{15}$.

Poza pewnym uproszczeniem w sprowadzeniu działań charytatywnych do aktu zaspokojenia „nagłej potrzeby pomagania”, komentarz ten słuszne stara się zróżnicować dwa omawiane rodzaje działań prospołecznych. Uwzględniając również potrzebę sensownego pokierowania tym obszarem aktywności obywatelskiej, Fundacja dla Polski opracowała pierwszy w Polsce Program Filantropii Indywidualnej, adresowany do osób zamożnych ${ }^{16}$. Tak właśnie można powiązać filantropię z działalnością organizacji non-profit, można też łączyć działalność filantropijną z charytatywną.

Podobne stanowisko do Fundacji dla Polski przyjmuje również Akademia Rozwoju Filantropii w Polsce (ARFP) - organizacja trzeciego sektora, budująca sieci partnerskich powiązań pomiędzy różnymi podmiotami, zajmująca się również wspieraniem rozwoju wolontariatu. Na stronie ARFP czytamy:

Wyobraź sobie świat, w którym ludzie ufają i pomagają sobie nawzajem, potrafią dzielić się z innymi i wspólnie rozwiązywać problemy.

15 Ibidem.

16 Ibidem. 
Czy jest to możliwe do osiągnięcia? Tak. Dzięki nowoczesnej filantropii. Nowoczesna filantropia to nie rozdawanie pieniędzy czy prezentowanie gotowych rozwiązan. To inspirowanie do działania i zmiany postaw życiowych. Właśnie taki świat pomagamy budować. Nie robimy tego sami. Akademia wraz z Partnerami zmienia świat na lepsze. W jaki sposób? Wspieramy lokalne społeczności, nagradzamy firmy zaangażowane społecznie, wyzwalamy w ludziach chęć pomagania. Dobro jest wszędzie, wystarczy je obudzić 17 .

Cóż zatem za ryzyko kryje się w działaniach charytatywnych i filantropijnych? Jednym z największych zagrożeń wydaje się „zła” pomoc, która zamiast zmieniać coś w życiu beneficjentów, umacnia ich tylko w bezradności i zależności ${ }^{18}$. Przykładem efektów niewłaściwego wspierania są np. zachowania lub postawy roszczeniowe, niechęć do zmiany, narastający brak wiary w jej możliwość czy czyste wygodnictwo. Przewodnik etyczny BBC (Ethics Guide BBC) wymienia całą listę potencjalnych negatywnych skutków działań swym zamiarze charytatywnych. W ich krytyce wskazuje się np. na to, że:

- dotyczą one objawów, ale nie usuwają przyczyn;

- zmieniają stan rzeczy, zamiast osoby będące w potrzebie;

- jako działania naprawcze wobec wadliwych rozwiązań, osłabiają osobowe mechanizmy reform społecznych; przynoszą "cudownie" ulgę, odwracając uwagę od istoty problemów;

- osłabiają pomysłowość i indywidualne motywacje do zmiany; wygaszają ducha reform i zdolność do samopomocy;

- odciążając państwo w wydatkach w danym obszarze, powodują ryzyko późniejszego niedofinansowana tego obszaru lub pokusę zaoszczędzenia na nim przez rząd;

- tworzą złudny substytut dobrobytu i bezproblemowości;

- zaburzają sprawiedliwość społeczną, poprzez faworyzowanie i uznaniowość wobec określonych podmiotów;

${ }_{17}$ Misja i zasady. Akademia Rozwoju Filantropii w Polsce, http://www.filantropia. org.pl/misja_i_zasady [dostęp: 2.05.2017].

18 Zob. D. Podgórska-Jachnik, op. cit., s. 45-52. 
- zaburzają mechanizmy społeczne i rynkowe;

- przez system zwolnień i odpisów, osłabiają system podatkowy;

- powodują utratę kontroli nad częścią środków, które można by było spożytkować na cele socjalne efektywniej;

- nie tworzą hierarchii społecznej użyteczności darowizn;

- moga przybierać postać dobroczynności egoistycznej (podejmowanej dla własnego dobrego samopoczucia, a nie dla czynienia dobra);

- mogą naruszać godność człowieka, a nawet jego prawa;

- zakłócają autonomię odbiorcy i jego mechanizmy samoregulacji ${ }^{19}$.

Oprócz tego BBC ostrzega przed polityczną manipulacją (realizacją ukrytych celów, innych niż deklarowane), nieefektywnym wykorzystywaniem środków, pozyskiwaniem ich w sposób nieetyczny, przedmiotowo wykorzystujące osoby, traktowane jako pretekstem do pozyskiwania środków ${ }^{20}$.

Wszystkie te zagrożenia należy brać pod uwagę w odniesieniu do działań charytatywnych, jednak nie oznacza to, że należy je ograniczać. Wręcz przeciwnie, charytatywność opartą na prawdziwej caritas oraz mądrą filantropię trzeba rozwijać, natomiast świadomość wymienionych zagrożeń powinna uruchomić krytyczną refleksję nad tym, jaką formę powinny one przybierać, jakie podjąć dodatkowe działania chroniące przed bylejakością, a tym bardziej nadużyciami. W tabeli 2. przedstawione zostały sugerowane działania zaradcze, jakie można podjać, by charytatywność spełniała swoje cele czynienia dobra, nie zła. Oczywiście nie wyczerpuje to repertuaru możliwych rozwiązań, jest jednak autorską propozycją opartą m.in. na własnych doświadczeniach współpracy z organizacjami pozarządowymi w obszarze wsparcia społecznego dla osób zagrożonych wykluczeniem społecznym - która ma skłonić czytelnika do własnych refleksji i własnych pomysłów. Przedstawione

${ }^{19}$ Ethics guide. Arguments against charity, BBC, 2014, http://www.bbc.co.uk/ ethics/charity/against_1.shtml [dostęp: 10.12.2016].

20 Ibidem. 
w tabeli środki zaradcze należy więc traktować nie jak sztywne zasady, ale materiał uwrażliwiający na problem i zachętę do tworzenia własnych rozwiązań prewencyjnych.

Tabela 2. Możliwości zapobiegania „złej” charytatywności w odniesieniu do obszarów zagrożeń wskazanych przez Ethics Guide BBC (źródło: opracowanie własne)

\begin{tabular}{|c|c|}
\hline $\begin{array}{c}\text { Potencjalne skutki ,złej” charytatywności wg } \\
\text { Ethics Guide BBC }\end{array}$ & Środki zaradcze \\
\hline Ingeruje w objawy - nie przyczyny & $\begin{array}{l}\text { Dobra diagnoza i współpraca z różnymi pod- } \\
\text { miotami na rzecz identyfikacji przyczyn pro- } \\
\text { blemów; reorientacja pomocy }\end{array}$ \\
\hline $\begin{array}{l}\text { Zmienia stan rzeczy - nie osoby w sytuacji pro- } \\
\text { blemowej }\end{array}$ & $\begin{array}{l}\text { Zastąpienie działań incydentalnych działaniami } \\
\text { długofalowymi (współpraca, aktywne/aktywi- } \\
\text { zujące wsparcie, charytatywność powiązana } \\
\text { z pracą socjalną }\end{array}$ \\
\hline $\begin{array}{l}\text { Kompensuje wadliwe rozwiązana - osłabia } \\
\text { mechanizmy reform społecznych, ukierunko- } \\
\text { wanych na istotę problemu }\end{array}$ & \multirow{2}{*}{$\begin{array}{l}\text { Komplementarność rozwiązania profilaktycz- } \\
\text { nych, reformatorskich i interwencyjno-kompen- } \\
\text { sacyjnych }\end{array}$} \\
\hline $\begin{array}{l}\text { Stwarza złudny substytut dobrobytu i braku } \\
\text { problemu }\end{array}$ & \\
\hline $\begin{array}{l}\text { Osłabia pomysłowość i indywidualną motywa- } \\
\text { cję do zmiany oraz zdolność zbiorowej samo- } \\
\text { pomocy }\end{array}$ & $\begin{array}{l}\text { Konsekwentna realizacja zasady pomocniczości, } \\
\text { wsparcie subsydiowane, kontrakty socjalne }\end{array}$ \\
\hline $\begin{array}{l}\text { Odciążając państwo w danym obszarze, stwarza } \\
\text { ryzyko oszczędzenia przez rząd środków na te } \\
\text { cele }\end{array}$ & $\begin{array}{l}\text { Demaskowanie obszarów zawodności państwa, } \\
\text { lobbing organizacji na rzecz rozwiązań docelo- } \\
\text { wych }\end{array}$ \\
\hline $\begin{array}{l}\text { Może niezasadnie faworyzować, prowadzić do } \\
\text { niesprawiedliwości i uznaniowości }\end{array}$ & $\begin{array}{l}\text { Pomoc systemowa, dobra diagnoza społeczna - } \\
\text { współpraca z pracownikami socjalnymi (wy- } \\
\text { wiad środowiskowy) }\end{array}$ \\
\hline $\begin{array}{l}\text { Zwiększa niezasadnie różnice między podmio- } \\
\text { tami, zaburzając mechanizmy społeczne i rynko- } \\
\text { we, w tym także mechanizm konkurencyjności }\end{array}$ & $\begin{array}{l}\text { Interwencyjność działań; zwiększenie zakresu } \\
\text { odpowiedzialność organizacji charytatywnych }\end{array}$ \\
\hline $\begin{array}{l}\text { Poprzez zwolnienia i odpisów osłabia system } \\
\text { podatkowy i kontrolę części środków, efektyw- } \\
\text { nie kierowanych na cele socjalne }\end{array}$ & \multirow{2}{*}{$\begin{array}{l}\text { Organizacje typu watchdog, transparentność } \\
\text { i upubliczniane rachunków organizacji }\end{array}$} \\
\hline $\begin{array}{l}\text { Nie zapobiega nieefektywnemu wydatkowaniu } \\
\text { środków przez organizacje charytatywne }\end{array}$ & \\
\hline
\end{tabular}




\begin{tabular}{|l|l|}
\hline \multicolumn{1}{|c|}{$\begin{array}{c}\text { Potencjalne skutki „złej” charytatywności wg } \\
\text { Ethics Guide BBC }\end{array}$} & \multicolumn{1}{|c|}{ Środki zaradcze } \\
\hline $\begin{array}{l}\text { Nie tworzy lub nawet zaburza hierarchię uży- } \\
\text { teczności społecznej, a tym samym nie sprzyja } \\
\text { użytecznym społecznie darowiznom }\end{array}$ & $\begin{array}{l}\text { Edukacja społeczna; rozwijanie postaw obywa- } \\
\text { telskich, zwiększenie aktywności partycypacyj- } \\
\text { nej }\end{array}$ \\
\hline $\begin{array}{l}\text { Zaspokaja egoistyczne motywy darczyńców, } \\
\text { niekoniecznie sprzyjając faktycznemu czynieniu } \\
\text { dobra }\end{array}$ & $\begin{array}{l}\text { Edukacja społeczna, rozwijanie postaw obywa- } \\
\text { telskich, lączenie darowizn z różnymi formami } \\
\text { kontaktu z beneficjentami }\end{array}$ \\
\hline Może naruszać godność człowieka i jego prawa & $\begin{array}{l}\text { Edukacja społeczna, rozwijanie asertywności, } \\
\text { stwarzanie przestrzeni do godnego przyjmowa- } \\
\text { nia pomocy }\end{array}$ \\
\hline $\begin{array}{l}\text { Może być zmanipulowana politycznie i realizo- } \\
\text { wać faktycznie inne cele od deklarowanych }\end{array}$ & $\begin{array}{l}\text { Demaskowanie faktycznych intencji, transpa- } \\
\text { rentność działań, organizacje typu watchdog }\end{array}$ \\
\hline $\begin{array}{l}\text { Stwarza przestrzeń dla nieetycznego fundraisin- } \\
\text { gu, w którym osoby są pretekstem do pozyski- } \\
\text { wania środków }\end{array}$ & $\begin{array}{l}\text { Edukacja społeczna, profesjonalizacja fundraisin- } \\
\text { gu i zawodowej działalności menadżerów spo- } \\
\text { lecznych, dyskusje etyczne }\end{array}$ \\
\hline $\begin{array}{l}\text { Zakłóca autonomię odbiorcy i jego mechanizmy } \\
\text { samoregulacji }\end{array}$ & $\begin{array}{l}\text { Konsekwentna realizacja zasady pomocniczości, } \\
\text { wsparcie subsydiowane, kontrakty socjalne, } \\
\text { przeciwdziałanie postawom roszczeniowym }\end{array}$ \\
\hline
\end{tabular}

Podsumowując zawarte w tabeli wskazania, można powiedzieć, że troska o "dobrą" charytatywność - na wyższym poziomie ogólności - opiera się przede wszystkim na trzech następujących filarach:

- edukacji społecznej, profesjonalizacji i kształtowania społecznej odpowiedzialności organizacji pozarządowych;

- zasadzie aktywizacji i pomocniczości, wyzwalającej tak zasoby organizacji, jak wspieranych jednostek (idea empowerment zgodna także $\mathrm{z}$ aktualnym kierunkiem rozwoju pomocy społecznej i pracy socjalnej);

- mechanizmach zewnętrznych, takich jak przeprowadzanie i dostarczenie niezależnych diagnoz lokalnych potrzeb społecznych, koordynacja działań różnych organizacji i tworzenie partnerstw, standaryzacja działań powierzanych i dofinansowywanych oraz sprawne funkcjonowanie mechanizmów kon- 
troli społecznej (organizacje strażnicze typu watchdog, kontrolujące zarówno działania instytucji rządowych, jak i pozarządowych); najlepiej, gdy ujęte jest to wszystko w lokalnych strategiach polityki społecznej, tworząc transparentne ramy podejmowanych działań charytatywnych.

W odniesieniu do pierwszego obszaru istotne są różnego rodzaju publikacje i portale kierowane do organizacji pozarządowych (na czele z ogólnopolskimi portalami www.ngo.pl oraz www.klon.org. pl/ngopl, które publikują nie tylko informacje, porady i poradniki, przykłady dobrej praktyk, ogłoszenia, ale także wyniki badań użytecznych w planowaniu mądrych i potrzebnych działań NGOs). Niestety, jak wynika z Raportu z badań Stowarzyszenia Klon/Jawor przeprowadzonych w roku 2012, diagnoza potrzeb beneficjentów w celu planowania działań pojawiała się jedynie w co trzeciej organizacji. Tylko tyle samo z nich dysponuje szczegółowymi informacjami na temat dotychczasowych beneficjentów, a niewiele ponad połowa $z$ tej grupy regularnie je analizuje czy próbuje ocenić skuteczność swoich działań. Tylko połowa organizacji szkoli pracowników, wolontariuszy lub inne osoby zaangażowane w realizowane działania21. Tak więc inwestycja w rozwój organizacji poprzez szkolenia, jak również badanie potrzeb społecznych i ewaluację działań nie należą do mocnych stron polskich organizacji pozarządowych, a powinno się to zmienić, jeśli oczekujemy ich profesjonalizacji.

Natomiast warto odnotować, iż w Klasyfikacji zawodów i specjalności na użytek rynku pracy w dziale Przedstawiciele władz publicznych (kod: 111) w kategorii 1114 Zawodowi działacze organizacji członkowskich pojawia się zawód oznaczony jako: 111403 Zawodowy działacz organizacji pozarządowej22. W syntetycznym opisie zawodu znajdują się m.in. następujące zadania:

${ }^{21}$ J. Przewłocka, P. Adamiak, J. Herbst, Podstawowe fakty o organizacjach pozarzadowych - raport z badania 2012. Seria: Badania Aktywności Obywatelskiej, Stowarzyszenie Klon/Jawor, Warszawa 2013, s. 196.

${ }^{22}$ Klasyfikacja zawodów i specjalności na potrzeby rynku pracy z 2014 r. zmieniona rozporządzeniem Ministra Rodziny, Pracy i Polityki Społecznej, zmieniającym 
[zawodowy działacz organizacji pozarządowej] określa, formułuje i wdraża program, cele i zasady organizacji pozarządowej; planuje, koordynuje i dokonuje oceny działalności oraz efektów pracy organizacji pozarządowej lub jej jednostek organizacyjnych; [...] promuje i wspiera interesy organizacji oraz jej członków wobec władzy ustawodawczej, wykonawczej i społeczeństwa; przedstawia sprawozdania władzom organizacji, członkom organizacji i agencjom finansującym; monitoruje i ocenia efekty działania organizacji pozarządowej $[\ldots]^{23}$.

Wymagania wobec zawodowych działaczy organizacji pozarządowych ${ }^{24}$ są dość duże, ale elastyczne, uwzględniające różne zasoby osobiste - np. wykształcenie czy doświadczenie (jak wynika z badań trzeci sektor wykazuje duże zróżnicowanie nie tylko celów i zakresu działań, ale także sposobu podziału pracy i obowiązków $^{25}$ ), czy nawet styl pracy w NGO. Okazuje się jednakże, że większość zawodowych działaczy ma wykształcenie wyższe oraz jakieś inne wcześniejsze doświadczenie zawodowe, a także najczęściej wcześniejsze doświadczenie w wolontariacie ${ }^{26}$.

Ponieważ w NGOs zrzeszane są często osoby, które poszukują reprezentacji zagrożonych interesów swojej grupy społecznej, skupiają one często osoby z niepełnosprawnością. Aktywność w orga-

Rozporządzenie $\mathrm{w}$ sprawie klasyfikacji zawód i specjalności na potrzeby rynku pracy oraz zakresu jej stosowania z dnia 7 listopada 2016 r. (Dz. U. z 2016 r., poz. 1876).

${ }^{23}$ Zawodowy działacz organizacji pozarzadowej, 111403, Synteza zawodu. Wojewódzki Urząd Pracy w Warszawie, http://wupwarszawa.praca.gov.pl/rynek-pra cy/bazy-danych/klasyfikacja-zawodow-i-specjalnosci/wyszukiwarka-opisow-zawo dow//-/klasyfikacja_zawodow/zawod/111403?_jobclassificationportlet_WAR_nnk portlet_backUrl=http\%3A\%2F\%2Fwupwarszawa.praca.gov.pl\%2Frynek-pracy \%2F bazy-danych\%2Fklasyfikacja-zawodow-i-specjalnosci\%2Fwyszukiwarka-opisow-za wodow \%2F\%2F-\%2Fklasyfikacja_zawodow\%2Flitera\%2FZ [dostęp: 20.06.2017].

${ }^{24}$ Zwanych w niektórych krajach (np. w Niemczech) menedżerami społecznymi - w Polsce słowo "działacz", choć powszechne, nie przez wszystkich przyjmowane jest dobrze.

${ }^{25}$ J. Przewłocka, P. Adamiak, J. Herbst, op. cit., s. 188.

${ }_{26}$ Polskie Organizacje Pozarzadowe 2015, http://fakty.ngo.pl/wiadomosc/18 89499.html [dostęp: 17.05.2017]. 
nizacjach może zaspokoić wiele ich potrzeb - np. potrzebę afiliacji, kontaktów społecznych, reprezentowania interesów, ale także szerzej rozumianą potrzebę aktywności społecznej i zawodowej. Szczególnie ta ostatnia zasługuje na uwagę, gdyż trzeci sektor stał się obecnie także potężnym pracodawcą, a więc i ważnym elementem aktywizacji zawodowej grup wrażliwych. Często zatrudniane w NGO są np. osoby z niepełnosprawnością. Z tego właśnie powodu Państwowy Fundusz Rehabilitacji Osób Niepełnosprawnych zamieścił na swojej stronie internetowej ciekawy materiał ukazujący możliwość spełnienia szczegółowych wymagań do zawodu działacza organizacji pozarządowej osób z różnego rodzaju niepełnosprawnością, wraz z instrukcjami dostosowania środowiska i organizacji pracy do ich potrzeb27.

W Polsce blisko połowa NGOs opiera się całkowicie na pracy społecznej, wolontariacie - członkowie $45 \%$ z organizacji nie pobierają żadnego wynagrodzenia ${ }^{28}$, co oznacza jednak, że już więcej niż połowa z nich spośród obecnie już 123975 organizacji pozarządowych w Polsce29, zatrudnia chociaż jedną lub kilka osób (choć są i takie, które zatrudniają ich kilkadziesiąt i więcej - to często większe organizacje o zasięgu ogólnopolskim). Jak wynika z badań, zarabianie pieniędzy w NGO częściej spotykane jest w stowarzyszeniach i fundacjach w dużych miastach, zwłaszcza w Warszawie, oraz w organizacjach dysponujących większymi budżetami ${ }^{30}$.

27 Zawodowy działacz organizacji pozarząowej, https://nowastrona.pfron.org.pl/ fileadmin/files/z/4147_Zawodowy_dzia_acz_organizacji.pdf [dostęp: 2.06.2017].

${ }^{28}$ A. Gałązka, I. Dutkiewicz, Ile i za co zarabiaja pracownicy NGO?, http://wia domosci.ngo.pl/wiadomosc/2005485.html [dostęp: 14.04.2017].

${ }^{29}$ Dane z 17.05.2017 r. Zob. Zespól badawczy Stowarzyszenia Klon/Jawor, 2017, Liczba NGO na świecie, http:/ / fakty.ngo.pl/wiadomosc/2069932.html [dostęp: 20.05.2017].

${ }^{30} \mathrm{~W}$ badaniach Stowarzyszenia Klon/Jawor procent organizacji, w których nikt z członków ani władz nie pobiera żadnego wynagrodzenia w związku z wykonywaną w niej pracą czy też na jej rzecz jest nawet wyższy - wynosi aż 72\%, ale były to badania wcześniejsze, niż cytowane wyżej ze strony ngo.pl. Zob. J. Przewłocka, P. Adamiak, J. Herbst, op. cit., s. 190. 
W pozostałych organizacjach procent środków przeznaczanych na wynagrodzenia jest zróżnicowany, przede wszystkim w zależności od rodzaju podejmowanej działalności: tam, gdzie w grę wchodzi np. pozyskiwanie, zakup i dystrybucja dóbr materialnych (np. drogiego sprzętu medycznego czy żywności) procentowy udział wynagrodzeń w sposób oczywisty będzie niższy, niż w przypadku dystrybucji usług (np. socjalnych, terapeutycznych, edukacyjnych), gdzie główny udział w kosztach stanowią wynagrodzenia dla zatrudnianych terapeutów. Portal Organizacji Pozarządowych podaje przykładowy udział wynagrodzeń w budżecie różnych organizacji w roku 2015. I tak w przypadku Wielkiej Orkiestry Świątecznej Pomocy udział ten wyniósł ok. 3,8\%, Federacji Polskich Banków Żywności - ok. 27\%. W przypadku dystrybucji pomocy materialnej i usług jest on nieco wyższy - np. w Caritas Archidiecezji Częstochowskiej kształtował się na poziomie ok. 39\%, w Katolickim Stowarzyszeniu Niepełnosprawnych Archidiecezji Warszawskiej ok. 49\%. Organizacje pełniące funkcje rzecznikowskie, eksperckie i świadczące usługi są najbardziej obciążone kosztami osobowymi, czego przykładem jest ich udział w budżecie Fundacji Rzecznika Praw Rodziców na poziomie aż ok. $70 \%{ }^{31}$.

Warto jednak zaznaczyć, że koszty pozyskiwania środków na działalność społeczną nie są małe. Uśredniając i pomijając opisane wyżej kwestie profilu NGO, jeśli ostatecznie do beneficjentów trafia ok. 65\% pozyskiwanych środków (koszty stanowią 35\%), można uznać taką organizację za działającą sprawnie pod względem ekonomicznym (choć sam procent nie gwarantuje automatycznie sensowności wydatków). W większości przypadków jest to ok. 50\%32. Tymczasem zdarza się i mniej sprawne zarządzanie, i próby wyłudzenia pieniędzy, stąd potrzeba sprawnych mechanizmów kontroli

${ }^{31}$ A. Gałązka, I. Dutkiewicz, op. cit.

32 Wskaźniki uzyskane w warunkach amerykańskich - w Polsce mogą się nieco różnić, ale brak porównywalnych badań. Zob. K. Hundley, K. Haggart, America's 50 worst charities rake in nearly $\$ 1$ billion for corporate fundraisers. Times/CIR special report, “Tampa Bay Times”, październik, 2014, http://www.tampabay.com/topics/ specials/worst-charities1.page [dostęp: 11.07.2017]. 
(społecznej). Tym bardziej, że przez trzeci sektor przepływa niemały strumień pieniędzy. W Polsce do potentatów działań filantropijnych zaliczyć należy nie tylko zamożne osoby prywatne, ale także organizacje pozarządowe - głównie $w$ formie organizacyjnej fundacji - o rocznych przychodach powyżej $1 \mathrm{mln}$ zł. Według danych z roku 2014 były to: Fundacja Dzieciom "Zdążyć z pomocą" (dochód $160 \mathrm{mln} 447$ tys. zł), Fundacja Wielkiej Orkiestry Świątecznej Pomocy (64 mln 425 tys. zł), Stowarzyszenie Wiosna $(41 \mathrm{mln}$ 236 tys. zł), Polska Akcja Humanitarna (33 mln 399 tys. zł), Wioski Dziecięce SOS (32 mln 426 tys. zł), Polski Czerwony Krzyż (29 mln 96 tys. zł), Caritas Polska (22 mln 400 tys. zł), Fundacja Polsat (12 mln 307 tys. zł), Fundacja TVN „Nie jesteś sam”, Fundacja „Mimo wszystko" Anny Dymnej (1 mln 348 tys. zł), Porozumienie Bez Barier Jolanty Kwaśniewskiej $\left(1 \mathrm{mln} 8\right.$ tys. zł) ${ }^{33}$. Są to organizacje rozpoznawalne, prezentujące nowoczesny model filantropii (przykładem znakomitych projektów na rzecz opisywanych relacji osobowych z beneficjentami jest np. akcja "Szlachetna paczka” Stowarzyszenia Wiosna), nie zawsze wysokość przychodów organizacji może być wskaźnikiem jej efektywności. Niestety, na tym polu także może dochodzić do nadużyć, co trafnie wykazali niezależni dziennikarze zrzeszeni w amerykańskiej organizacji typu watchdog o nazwie Tampa Bay Times.

Jednym z celów organizacji Tampa Bay Times jest demaskowanie największych nadużyć, do których dochodzi pod płaszczem charytatywności. Na swoim portalu organizacja publikuje wyniki finansowe najgorszej amerykańskiej pięćdziesiątki NGOs (America's 50 worst charities) ${ }^{34}$, deklarującej dobroczynność o łącznym dochodzie znacznie ponad bilion dolarów oraz opisy działań nieudolnych, skrajnie nieprofesjonalnych. Jak ujawnia Tampa Bay Times, $\mathrm{w}$ tych wielkich czasem korporacjach pozyskujących ogromne

${ }^{33}$ M. Ratajczak, Ile zbieraja najbardziej znane polskie organizacje dobroczynne? Sprawdzamy ich przychody. Portal internetowy money.pl https://www.money.pl/ gospodarka/wiadomosci/artykul/ile-zbieraja-najbardziej-znane-polskie,151,0,1991 575.html [dostęp: 20.06.2017].

${ }^{34}$ K. Hundley, K. Haggart, op. cit. 
środki finansowe, zdecydowana większość dochodów - ponad 70\% - przeznaczana jest na wynagrodzenia dla prawników, nieco ponad $26 \%$ stanowi cały pozostały budżet organizacji (w tym wynagrodzenia zatrudnionych tam działaczy, a bezpośrednio do beneficjentów trafia jedynie... ok. 3,5\% całości. To średnia „najgorszej pięćdziesiątki" - w najgorszych z najgorszych opisanych organizacjach do beneficjentów trafiało od zera do 1\% zebranych środków ${ }^{35}$.

Czy nadużycia w trzecim sektorze są argumentem przeciwko jego działalności? Absolutnie nie: to wyjątkowo ważny obszar aktywności społecznej gospodarczej dla współczesnego państwa i bardzo istotny jest jego rozwój - szczególnie w obszarze działań woluntarystycznych. Jednak demaskowanie nadużyć oraz zapobieganie im oraz ulepszanie jakości funkcjonowania organizacji słabych są jednak bardzo ważnym zadaniem, gdyż naruszają one zaufanie społeczne do działalności charytatywnej i filantropii, zamiast więc zachęcać społeczeństwo do uczestnictwa w nich i solidarności z potrzebującymi - mogą wywołać efekt odwrotny. Nie można też dopuścić, by organizacje słabe, nieudolne czy nieuczciwe rzucały cień na te, które wykonują wartościową społecznie pracę. O jej formach, treściach, metodach - można dyskutować, pod warunkiem wspomnianego zwiększenia profesjonalizacji działań.

Pozostaje jeszcze pytanie, czy dobroczynność i charytatywność to działania, które należy współcześnie brać pod uwagę w rozwiązywaniu problemów związanych z niepełnosprawnością? Czy stanie się obiektem charytatywności nie narusza godności ${ }^{36}$, wizerunku oraz sił samoregulacyjnych tych osób? To zależy już od dobrego rozpoznania potrzeb oraz sposobu prowadzenia działań wspierających, jak również od konsekwentnego, podmiotowego traktowania osób z niepełnosprawnością. Oznacza to np. możliwość zabierania głosu we własnych sprawach, dokonywania wyborów (czasem muszą być to decyzje wspierane), także aktywnego działania we wła-

35 Ibidem.

36 B. Szczupał, Godność osoby z niepetnosprawnością. Studium teoretyczno-empiryczne poczucia godności młodzieży z dysfunkcją narządu ruchu, Akapit, Warszawa 2011. 
snym imieniu. Warto tez zauważyć, że coraz więcej osób niepełnosprawnych otwarcie sprzeciwia się tradycyjnej charytatywności, zwłaszcza tej opartej na litości. Nie znaczy to, że będąc niepełnosprawnymi, nie potrzebują pomocy, ale powinna to być pomoc na miarę XXI w., wpisująca się w procesy inkluzji społecznej ${ }^{37}$ i społeczny model niepełnosprawności oznaczający m.in. wspólną odpowiedzialność społeczeństwa za wynikające $\mathrm{z}$ tejże niepełnosprawności problemy ${ }^{38}$. Poza tym od razu trzeba jasno powiedzieć, że skala niepełnoprawności i wynikających z nich problemów jest na tyle duża, że z pewnością trudno liczyć na załatwienie wszystkich kwestii społecznych przez państwo, a waga ich w odniesieniu do omawianej grupy osób wzrasta jeszcze po ratyfikacji przez Polskę Konwencji o Prawach Osób Niepełnosprawnych ${ }^{39}$. Choć założona równość w prawach w jakiś sposób może zaprzeczać podejściu charytatywnemu, to jednak w zasobach działań dobroczynnych uzyskujemy narzędzia kompensacji praw zagrożonych, szczególnie w obszarach, w których trudno jest zrealizować postanowienia Konwencji bez pomocy i wsparcia innych (np. tak jest $\mathrm{z}$ prawem prokreacyjnym lub prawo do tych osób do własnego/niezależnego miejsca zamieszkania).

Oprócz ubóstwa, wskazanego w podanych definicjach charytatywności i filantropii, także niepełnosprawność od dawna była tradycyjnym obszarem działań wspierających, choć formy tego wsparcia ewoluowały. Także i obecnie w działaniach organizacji pozarządowych należy uwzględniać nie tylko nowe podejście do polityki społecznej, ale i nowe podejście do niepełnosprawności. Są

37 M.A. Winzer, The inclusion movement. Review and reflections on reform in special education, [w:] Special education in the 21th century. Issues of inclusion and reform, red. M.A. Winzer, K. Mazurek, Gallaudet University Press, Waszyngton 2000.

38 C. Barnes, G. Mercer, Niepetnosprawność, Wydawnictwo Sic!, Warszawa 2008; I. Hacking, The social construct of what?, MA - London: Harvard University Press, Cambridge 1999; L. Sibilski, Social Aspects of Disability: Social Movements, Social Organization, and Legislative Action, Wydawnictwo Naukowe "Śląsk", Katowice 2000.

${ }^{39}$ Konwencja o prawach osób niepełnosprawnych, sporządzona w Nowym Jorku dnia 13 grudnia 2006 r. (Dz. U. z 2012 r., poz. 1169). 
one zaprzeczeniem obrazu biernej, zależnej osoby, która z powodu niepełnosprawności staje się przedmiotem działań opiekunczych, w tym działań charytatywnych. Należy przy tym dodać, że nowe trendy w polityce społecznej - w tym pomocy społecznej i pracy socjalnej - są wyjątkowo zbieżne z nowym podejściem do niepełnosprawności. W nowych, aktywnych i aktywizujących działaniach pomocowych wyraża się więc zgodność ze współczesną pedagogiką specjalną, należy jednak poddać krytycznej ocenie, czy rzeczywiście $\mathrm{w}$ praktyce mamy do czynienia $\mathrm{z}$ realizacją tych założeń.

\section{Bibliografia}

Barnes C., Mercer G., Niepetnosprawność, Wydawnictwo Sic!, Warszawa 2008.

Gogacz M., Wprowadzenie do etyki chronienia osób, Wydawnictwo Navo, UKSW, Warszawa 1998.

Hacking I., The social construct of what?, MA - London: Harvard University Press, Cambridge 1999.

Obszary społecznej marginalizacji - niepetnosprawność, red. J. Rutkowiak, A. Krause, OSW im. J. Rusieckiego, Olsztyn 2009.

Podgórska-Jachnik D., Praca socjalna $z$ osobami z niepetnosprawnościa $i$ ich rodzinami, CRZL, Warszawa 2014.

Przewłocka J., Adamiak., P., Herbst J, Podstawowe fakty o organizacjach pozarzadowych - raport z badania 2012. Seria: Badania Aktywności Obywatelskiej, Stowarzyszenie Klon/Jawor, Warszawa 2013.

Sibilski L., Social Aspects of Disability: Social Movements, Social Organization, and Legislative Action, Wydawnictwo Naukowe „Śląsk”, Katowice 2000.

Spytek-Bandurska G., Sektor, podmioty, poziomy i organizacja polityki społecznej, [w:] Polityka społeczna, red. G. Firlit-Fesnak, M. Szylko-Skoczny, Wydawnictwo Naukowe PWN, Warszawa 2009.

Szczepankowski B., Historia ruchu głuchoniemych. Publikacja wydana z okazji 120-lecia ruchu społecznego niestyszacych na ziemiach polskich oraz 50-lecia Polskiego Zwiazku Głuchych, PZG, Warszawa 1997.

Szczupał B., Godność osoby z niepetnosprawnością. Studium teoretyczno-empiryczne poczucia godności młodzieży z dysfunkcją narządu ruchu, Akapit, Warszawa 2011.

Winzer M.A., The inclusion movement. Review and reflections on reform in special education, [w:] Special education in the 21th century. Issues of inclusion and reform, red. M.A. Winzer, K. Mazurek, Gallaudet University Press, Waszyngton 2000. 
Wykaz aktów prawnych

Klasyfikacja zawodów i specjalności na potrzeby rynku pracy z 2014 r. zmieniona rozporządzeniem Ministra Rodziny, Pracy i Polityki Społecznej, zmieniającym Rozporządzenie $\mathrm{w}$ sprawie klasyfikacji zawód i specjalności na potrzeby rynku pracy oraz zakresu jej stosowania z dnia 7 listopada 2016 r. (Dz. U. z 2016 r., poz. 1876).

Konwencja o prawach osób niepełnosprawnych, sporządzona w Nowym Jorku dnia 13 grudnia 2006 r. (Dz. U. z 2012 r., poz. 1169).

Obwieszczenia Marszałka Sejmu Rzeczypospolitej Polskiej z dnia 1 lutego 2016 r. w sprawie ogłoszenia jednolitego tekstu ustawy o działalności pożytku publicznego i o wolontariacie (Dz. U. z 2010 r. Nr 28, poz. 146).

Ustawa z dnia 24 kwietnia 2003 r. o działalności pożytku publicznego i o wolontariacie (Dz. U. z 2003 r. Nr 96, poz. 873).

Wykaz stron internetowych [dostęp: 22.04-11.07.2017]

http://fakty.ngo.pl/wiadomosc/2069932.html

http://www.filantropia.org.pl/misja_i_zasady

http://osektorze.ngo.pl

https://sjp.pwn.pl/doroszewski/dobroczynnosc;5421107.html

https://sjp.pl/filantropia

http://wiadomosci.dziennik.pl/wydarzenia/artykuly/307049,filantropia-polacynie-znaja-tego-slowa.html

http://wiadomosci.ngo.pl/wiadomosc/2005485.html

http://wupwarszawa.praca.gov.pl/rynek-pracy/bazy-danych/klasyfikacja-zawo dow-i-specjalnosci/wyszukiwarka-opisow-zawodow//-/klasyfikacja_zawodow / zawod/111403?_jobclassificationportlet_WAR_nnkportlet_backUrl=http\%3A\% 2F\%2Fwupwarszawa.praca.gov.pl\%2Frynek-pracy\%2Fbazy-danych\%2Fklasyfi kacja-zawodow-i-specjalnosci\%2Fwyszukiwarka-opisow-zawodow $\% 2 \mathrm{~F} \% 2 \mathrm{~F}-\% 2$ Fklasyfikacja_zawodow\%2Flitera \%2FZ

http://fakty.ngo.pl/wiadomosc/1889499.html

https://nowastrona.pfron.org.pl/fileadmin/files/z/4147_Zawodowy_dzia_acz_or ganizacji.pdf

http://www.bbc. co.uk/ethics/charity/against_1.shtml

http://www.dailymail.co.uk/news/article-2822829/Charity-worker-90-arrested-po

lice-feeding-homeless-gets-right-work-one-day-later-despite-outcry-insensitivemayor-gets-arrested-again.html

https://www.money.pl/gospodarka/wiadomosci/artykul/ile-zbieraja-najbardziejznane-polskie,151,0,1991575.html

http://www.ngo.pl/files/biblioteka.ngo.pl/public/ksiazki/Klon/elementarz_III_ sektora.pdf

http://www.tampabay.com/topics/ specials/worst-charities1.page 